\title{
Mutations showing specificity for normal growth or Mn(II)-dependent post-exponential- phase cell division in Deinococcus radiodurans
}

\author{
Chi Luan Lin, Chich Sheng Lin and Shieh Te Tan \\ Author for correspondence: Shieh Te Tan. Tel: +886 35 721414. Fax: +88635726283. \\ e-mail: sttan@RB.nthu.edu.tw
}

Institute of Radiation

Biology, National Tsing Hua

University, Hsinchu 30043,

Taiwan, Republic of China

\begin{abstract}
We have previously reported that in the presence of small amounts of Mn(II) ions, stationary-phase cultures of the radioresistant bacterium Deinococcus radiodurans IR are capable of undergoing about three new rounds of cell division which are non-exponential and reductive. This novel Mn(II)-induced cell division (Mn-CD) phenomenon was studied further. Two mutants were isolated from $D$. radiodurans IR and were found to harbour mutations affecting the continuation of cell division and DNA replication, one of which affected vegetative growth but not Mn-CD, while the other affected Mn-CD but not vegetative growth. Moreover, a DNA synthesis transition was observed when growth was switched from the normal to the Mn-CD process. These results suggest the presence in $D$. radiodurans of an alternative type of cell division induction, which is characterized by being $\mathrm{Mn}$ (II)-dependent and stationary-phase specific.
\end{abstract}

Keywords: Deinococcus radiodurans, cell division, manganese(II), temperature-sensitive mutant

\section{INTRODUCTION}

The members of the genus Deinococcus, a phylogenetic outrider among bacteria (Woese, 1987), are known for their extreme resistance to the lethal effects of UV $(254 \mathrm{~nm})$ and ionizing radiations (Anderson et al., 1956; Moseley, 1983; Murray, 1992).

Regarding this radioresistance, the divalent cation $\mathrm{Mn}$ (II) is of particular interest. It has been reported that $\mathrm{Mn}$ (II) is bound to chromosomal DNA in large amounts in Deinococcus (formerly Micrococcus) radiodurans (Leibowitz et al., 1976), is required for the activity of a DNA repair enzyme (Evans \& Moseley, 1985), and is involved in the high radioresistance in this bacterium (Wierowski \& Bruce, 1980). Recently, we found that addition of $\mathrm{Mn}$ (II) at $2.5 \mu \mathrm{M}$ or higher to stationary-phase cultures of $D$. radiodurans IR was capable of triggering new rounds of cell division (Chou \& Tan, 1990). This cell division induction was termed ' $\mathrm{Mn}$ (II)-induced cell division' (Mn$\mathrm{CD})$. Cells in the Mn-CD stage lose resistance to both UV and gamma radiations as a function of the number of $\mathrm{Mn}$ CDs (Chou \& Tan, 1990). In addition to the increased sensitivity to radiation-induced cell inactivation, physio-

Abbreviations: $\mathrm{Mn}-\mathrm{CD}, \mathrm{Mn}(\mathrm{II})$-induced cell division; $\mathrm{N}-\mathrm{CD}$, normal cell division. logical changes accompanied by the $\mathrm{Mn}$-CD effect include a shortened stationary phase before rapid death of the culture as well as an increase in both superoxide dismutase and catalase activities. $\mathrm{Mn}-\mathrm{CD}$ apparently results from a change in growth control by either disrupting or bypassing a cell division arrest (Chou \& Tan, 1990). The Mn-CD effect appears to be $\mathrm{Mn}$ (II) and Deinococcusspecific. Little is, however, known about the mechanism(s) involved.

The nature of $\mathrm{Mn}-\mathrm{CD}$ is further clarified and discussed in this report. Cell division cycle mutants, including a temperature-sensitive mutant and an Mn-CD-negative mutant, have been isolated in this study. The physiological and genetic analyses of these different cell division cycle mutants suggest the presence in $D$. radiodurans of an alternative pathway in the cell division cycle which is activated by $\mathrm{Mn}$ (II) and operates only in the stationary phase; that is, the pathways of normal cell division (N$\mathrm{CD}$ ) and $\mathrm{Mn}-\mathrm{CD}$ appear to be separable in certain step(s).

\section{METHODS}

Strain, media, and growth conditions. D. radiodurans IR, formerly Micrococcus isolate C-7, has been characterized previously (Tan, 1982; Tan \& Maxcy, 1982, 1986; Chou \& Tan, $1990,1991)$. Growth conditions were described previously (Chou \& Tan, 1990). Unless otherwise specified, cell cultivation 
was at $32{ }^{\circ} \mathrm{C}$. Liquid cultivation was performed routinely with shaking at 160 r.p.m. in plate count broth (PCB; Difco) containing $5 \mathrm{~g}$ yeast extract, $10 \mathrm{~g}$ tryptone, and $2 \mathrm{~g}$ dextrose $\mathrm{l}^{-1}$. Plate count agar (PCA; Difco) was used in cell enumeration by the standard plate count method as previously described (Tan \& Maxcy, 1982). Phosphate buffer $(67 \mathrm{mM}, \mathrm{pH} 7 \cdot 0)$ was used for washing, suspending and diluting bacteria. $\mathrm{MnSO}_{4} \cdot \mathrm{H}_{2} \mathrm{O}$ (E. Merck) of analytical grade was used to prepare the $\mathrm{Mn}$ (II) solution.

Determination of cell size. Cell samples appropriately diluted with an electrolyte solution (ISOTON II, Coulter Electronics) were analysed for cell size by using a particle analyser (Coulter Multisizer II, Coulter Electronics) (Kubitschek, 1990).

Test for Mn-CD effect. Overnight culture $(0.1 \mathrm{ml})$ was transferred to two test-tubes (each containing $10 \mathrm{ml} \mathrm{PCB}$ ) and incubated until reaching the early stationary phase. $\mathrm{Mn}$ (II) was added to one of the tubes at $10 \mu \mathrm{M}$, and both of the tubes were further shaken for $12 \mathrm{~h}$ (for a full expression of $\mathrm{Mn}-\mathrm{CD}$ ). A higher turbidity in the $\mathrm{Mn}$ (II) tube due to reductive cell divisions was regarded as a result of the Mn-CD effect.

Isolation of mutants. For all mutagenesis treatments, the lateexponential-phase cells were washed and resuspended in phosphate buffer before adding $N$-methyl- $N^{\prime}$-nitro- $N$-nitrosoguanidine [NTG, dissolved in dimethyl sulfoxide/phosphate buffer $(3: 7, \mathrm{v} / \mathrm{v})]$ at dosages causing an approximate $50 \%$ reduction in cell viability.

(i) Temperature-sensitive mutant. NTG-treated $D$. radiodurans IR cells were washed twice with phosphate buffer, resuspended in PCB, and incubated overnight. The culture was then properly diluted and plated on PCA to yield 100-200 colonies per plate after incubation for 2-3 d. Discrete colonies were transferred with a toothpick onto PCA plates such that two replicate copies of each plate were made, one of which was incubated at $32^{\circ} \mathrm{C}$ and the other at $39^{\circ} \mathrm{C}$. After overnight incubation, colonies which grew at $32^{\circ} \mathrm{C}$, but not at $39^{\circ} \mathrm{C}$, were isolated and tested to verify the temperature sensitivity.

(ii) Mn-CD-negative mutant. To increase the chance of isolating Mn-CD-negative mutants of interest, two enrichment steps were designed (because no information concerning the Mn-CD phenomenon and its genetic background is available). The first of these was enrichment of mutants by heat treatment. The $\mathrm{Mn}-\mathrm{CD}$ cells of $D$. radiodurans IR were previously found to be more sensitive to a lethal temperature than untreated control cells. When NTG-treated cells were grown in PCB with $10 \mu \mathrm{M}$ $\mathrm{Mn}$ (II) until reaching the end of $\mathrm{Mn}-\mathrm{CD}$, and heated at $60^{\circ} \mathrm{C}$ for $20 \mathrm{~min}, \mathrm{Mn}-\mathrm{CD}$-negative mutants would be enriched. The second enrichment step involved distinction of colony size on $\mathrm{Mn}$ (II)-supplemented agar plates. As it lacks $\mathrm{Mn}$ (II)-mediated 'extra' cell divisions, the Mn-CD-negative mutant would form colonies smaller than that of the wild-type ( $\mathrm{Mn}-\mathrm{CD}$ positive) strain on $\mathrm{Mn}(\mathrm{II})$-containing agar plates. Thus, heat-treated cells were spread on PCA containing $10 \mu \mathrm{M} \mathrm{Mn}(\mathrm{II})$. Colonies with a relatively small size on PCA would be picked up and further tested for the Mn-CD effect (see earlier).

Measurement of DNA synthesis. A modified method of that described by Boylan \& Mendelson (1969) was used to measure DNA synthesis. Briefly, $\left[\right.$ metbyl $\left.l^{3} \mathrm{H}\right]$ thymidine $\left[6.7 \mathrm{Ci} \mathrm{mmol}^{-1}\right.$ $\left.\left(247.9 \mathrm{GBq} \mathrm{mmol}^{-1}\right)\right]$ was added to give a final activity of $20 \mu \mathrm{Ciml}^{-1}\left(740 \mathrm{kBqml}^{-1}\right)$ to the cultures grown in PCB supplemented with $100 \mu \mathrm{g}$ thymidine $\mathrm{ml}^{-1}$. Samples $(0.1 \mathrm{ml})$ were removed at various times and added to $10 \mathrm{ml}$ ice-cold $10 \%$ $(\mathrm{v} / \mathrm{v})$ TCA. The acid-insoluble fraction was collected by centrifugation (6000 r.p.m.; $5 \mathrm{~min}$ ) and washed separately three times with $10 \mathrm{ml} 5 \%(\mathrm{v} / \mathrm{v})$ TCA. The radioactivity in the acid- insoluble fraction suspended in $3 \mathrm{ml}$ of a scintillation counting solution was determined with a liquid scintillation counter.

\section{RESULTS AND DISCUSSION}

\section{Isolation of a temperature-sensitive mutant that fails to grow, but retains Mn-CD demonstrability, at the restrictive temperature}

After an NTG $\left(0.5 \mathrm{gl}^{-1}\right)$ treatment, a mutant that grew at $32{ }^{\circ} \mathrm{C}$ but not at $39^{\circ} \mathrm{C}$ was isolated from about 5000

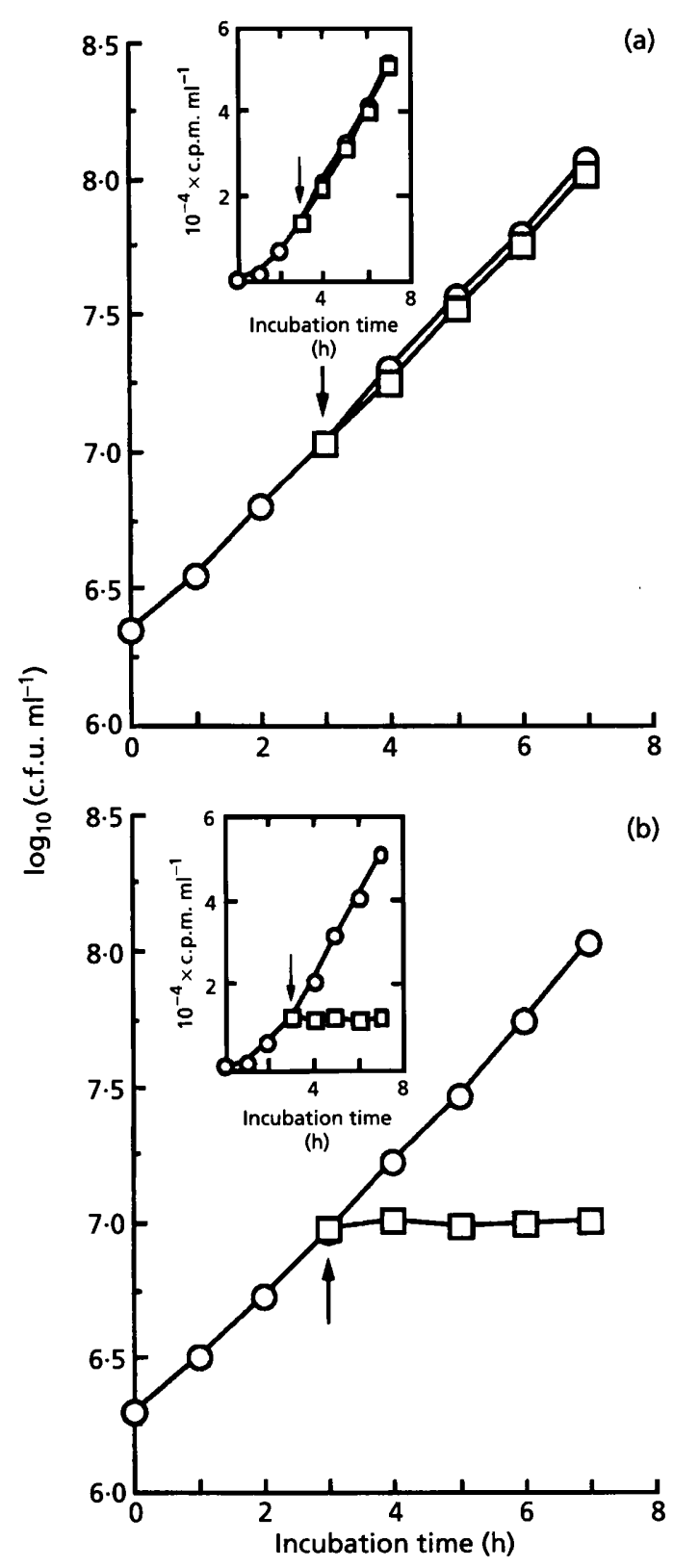

Fig. 1. Growth and $\left[{ }^{3} \mathrm{H}\right]$ thymidine incorporation (inset) of $D$. radiodurans $\mathrm{IR}$ (a) and its temperature-sensitive mutant TS1 (b). Cultures were grown in PCB and the temperature was shifted to $39^{\circ} \mathrm{C}(\square)$ after $3 \mathrm{~h}$ at $32{ }^{\circ} \mathrm{C}(\mathrm{O})$ as indicated by arrows. Data for growth measurement are means of at least two replications. Individual points of radioactivities represent the mean of three independent measurements differing by less than $10 \%$. 


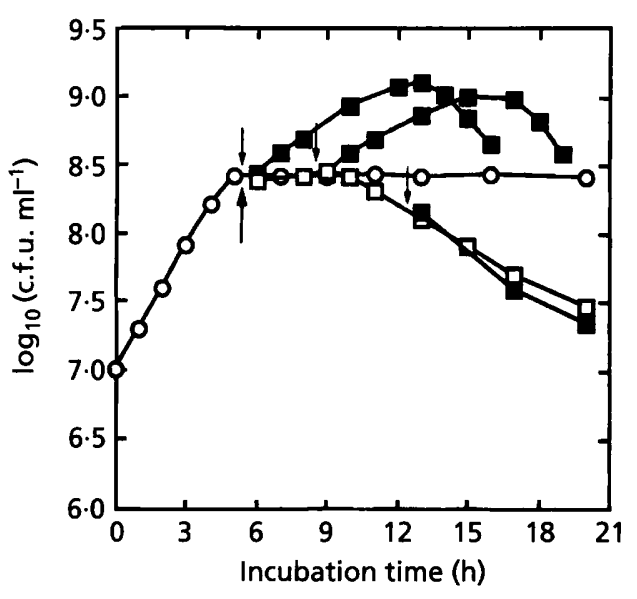

Fig. 2. $M n-C D$ of stationary-phase $T S 1$ cells at the restrictive temperature $\left(39^{\circ} \mathrm{C}\right)$. Cultures were pregrown at $32^{\circ} \mathrm{C}$ to the stationary phase in $\mathrm{PCB}$, and the temperature was then shifted to $39^{\circ} \mathrm{C}$ as indicated by the large arrow. $O, 32^{\circ} \mathrm{C} ; \square, 39^{\circ} \mathrm{C} ;$ $39^{\circ} \mathrm{C}$ with $\mathrm{Mn}$ (II). The times of $\mathrm{Mn}$ (II) addition are indicated by the small arrows. Data are means of at least three replications.

survivors. Growth and DNA synthesis of this mutant (TS1) in PCB were immediately halted following the temperature shift from $32{ }^{\circ} \mathrm{C}$ to $39{ }^{\circ} \mathrm{C}$, whereas those of IR remained unaffected (Fig. 1). Evidently, TS1 was a temperature-sensitive mutant whose $\mathrm{N}-\mathrm{CD}$ pathway was blocked at the restrictive temperature $\left(39^{\circ} \mathrm{C}\right)$. Interestingly, the stationary-phase cultures of TS1 (grown at $32^{\circ} \mathrm{C}$ ) could undertake further cell division at not only $32{ }^{\circ} \mathrm{C}$ (data not shown) but also $39^{\circ} \mathrm{C}$ (Fig. 2) upon the addition of $10 \mu \mathrm{M} \mathrm{Mn}(\mathrm{II})$. This suggests that the $\mathrm{Mn}-\mathrm{CD}$ and the N-CD pathways appear to be separable from each other. These results also suggest that in TS1 the temperature-sensitive mutation(s) might be in a gene coding a specific component needed for DNA synthesis and expressed in exponential-phase cells. This specific component is essential for the N-CD process, whereas it is not involved in, nor essential for, the Mn-CD process. We propose the presence of an $\mathrm{Mn}$ (II)-dependent component that is required for DNA synthesis of $\mathrm{Mn}-\mathrm{CD}$ process in stationary-phase cells of $D$. radiodurans IR.

Additionally, it was noted that the wild-type strain and TS1 both showed earlier transition from stationary phase into death phase at $39^{\circ} \mathrm{C}$, with or without added $\mathrm{Mn}$ (II) (TS1 data shown in Fig. 2).

\section{The Mn-CD mechanism is activated only when a culture has entered the stationary phase}

To determine whether activation of the Mn-CD mechanism could occur in an exponential-phase culture of TS1, an overnight culture of TS1 was inoculated into PCB at a low initial cell density (approximately $10^{3}$ c.f.u. $\mathrm{ml}^{-1}$ ) and then cultivated at $32{ }^{\circ} \mathrm{C}$. Cultures at the mid-exponential, late-exponential and early-stationary phases (approximately $5 \times 10^{6}, 5 \times 10^{7}$, and $2 \times 10^{8}$ c.f.u. $\mathrm{ml}^{-1}$, respect-
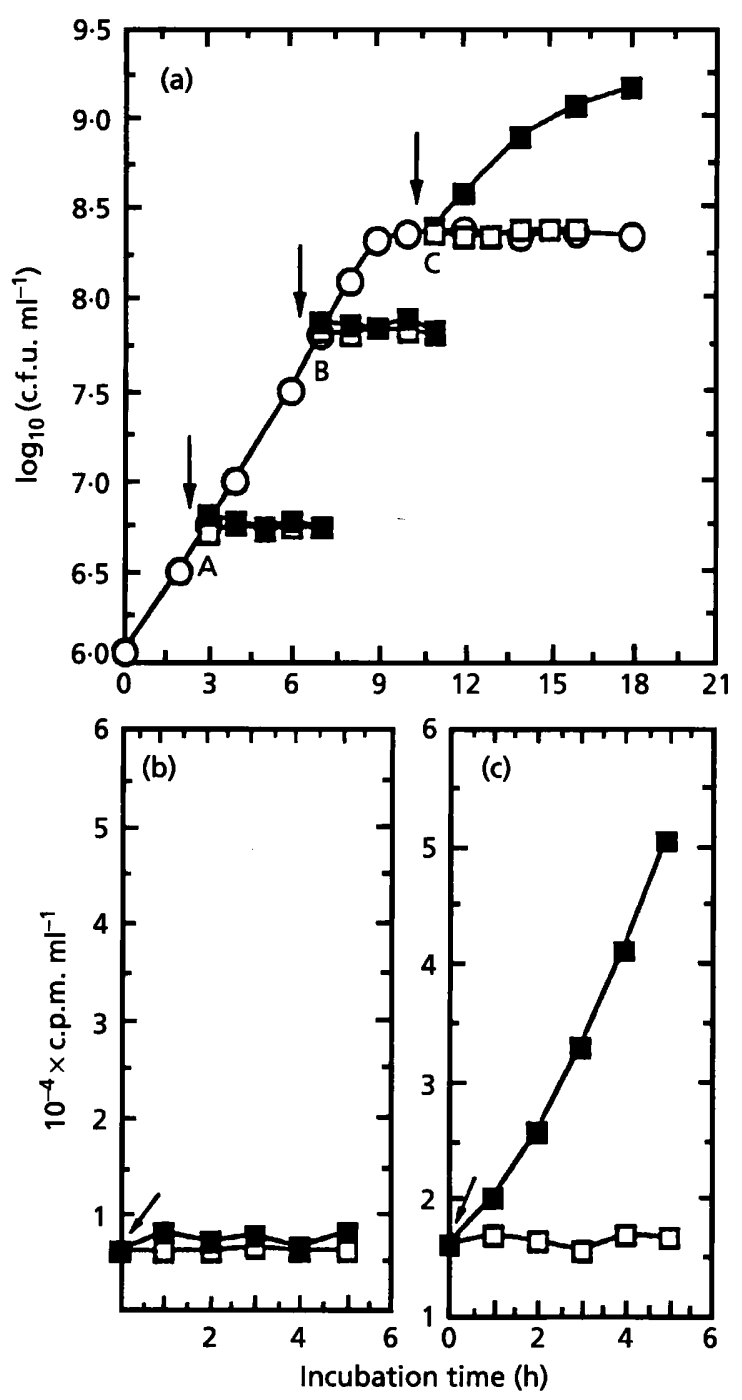

Fig. 3. Effects of temperature shift from $32^{\circ} \mathrm{C}(O)$ to $39^{\circ} \mathrm{C}$ $(\square, \square)$ on growth $(a)$ and $\left[{ }^{3} \mathrm{H}\right]$ thymidine incorporation $(b, c)$ of the exponential-phase (A, B) and stationary-phase (C) cultures of a temperature-sensitive mutant TS1 with $(\square)$ or without $(\square)$ $\mathrm{Mn}$ (II) addition. Parts (b) and (c) show the incorporation data from the cultures represented by $A$ and $C$ in part (a), respectively. Arrows indicate the times of temperature shift plus $\mathrm{Mn}$ (II) addition. Data for growth measurement are means of at least two replications. Individual points of radioactivities represent the mean of three independent measurements differing by less than $10 \%$.

ively) were each treated with $\mathrm{Mn}(\mathrm{II})$ at $10 \mu \mathrm{M}$ and shifted to $39{ }^{\circ} \mathrm{C}$. Samples were then taken at intervals for determining the further cell division and DNA synthesis. The results indicated that the stationary-phase cultures could demonstrate Mn-CD (Fig. 3a) and DNA synthesis (Fig. 3c) at $39^{\circ} \mathrm{C}$, whereas both the mid- and lateexponential phase cultures [in a sense these cultures entered a stationary (more accurately, static) phase after shifting to $39^{\circ} \mathrm{C}$ ] could not (Fig. 3a, b). These results suggest that only the cells physiologically entering the stationary phase are capable of demonstrating the Mn-CD 


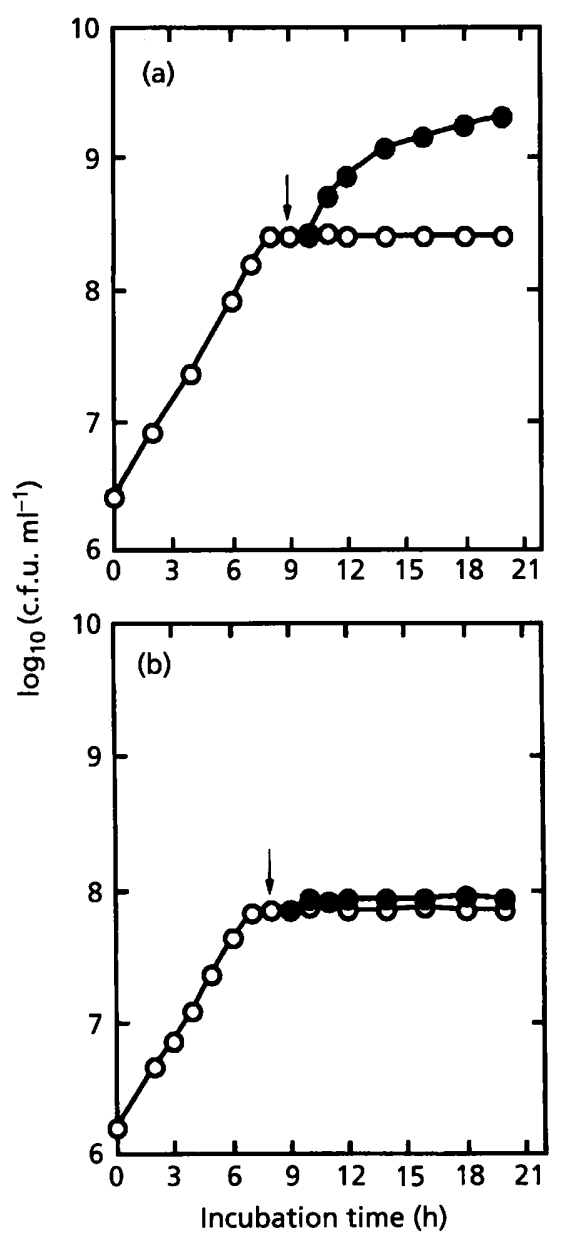

Fig. 4. Growth of $D$. radiodurans $I R(a)$ and its $M n-C D$-negative mutant D1 (b) in PCB at $32{ }^{\circ} \mathrm{C}(\mathrm{O})$ and their responses to $\mathrm{Mn}(\mathrm{II})$ addition (O) in the stationary phase. Arrows indicate the times of $\mathrm{Mn}$ (II) addition. Data are means of at least two replications.

phenomenon, while the exponential-phase cells physically forced to enter a nongrowing phase are not. It appears that the Mn-CD pathway is normally blocked in the exponential phase and that some gene(s) is activated to initiate $\mathrm{Mn}-\mathrm{CD}$ in the stationary phase, whereas the N-CD pathway would prevail in the exponential phase.

Certain cellular proteins were found to increase with time of Mn-CD (Chou \& Tan, 1990). Mn(II) may be involved in an initiation process of cell division; it either induces $d e$ novo protein synthesis or causes activity changes in preexisting stationary-phase specific protein(s). Stationaryphase specific proteins have been shown in Escherichia coli (Groat et al., 1986; Jenkins et al., 1990; Siegele \& Kolter, 1992), Salmonella typhimurium (Spector et al., 1986) and Vibrio sp. (Nyström et al., 1990). The Mn-CD effect presents a novel example to stress the generality of stationary-phase phenomonology; other examples include sporulation in Bacillus subtilis (Nicholson \& Setlow, 1990; Oke \& Losick, 1993), production of secondary metabolites in Streptomyces spp. (Bascarán et al., 1991;
Gramajo et al., 1993), and storage metabolism in Saccharomyces cerevisiae (Lillie \& Pringle, 1980).

\section{The Mn-CD mechanism is not essential for cell viability and multiplication}

As indicated above, DNA replication of the N-CD but not $\mathrm{Mn}-\mathrm{CD}$ process in TS1 was blocked at $39^{\circ} \mathrm{C}$, suggesting that the $\mathrm{Mn}-\mathrm{CD}$ process possibly involves an alternative DNA replication pathway. Therefore, blocking the Mn-CD-dependent pathway would not be lethal to the cell, and it should be possible to isolate mutants which are defective in $\mathrm{Mn}-\mathrm{CD}$.

About 20000 NTG-mutagenized IR cells were enriched for Mn-CD-negative mutants. Finally, about 2000 colonies were subjected to the Mn-CD test and an Mn-CDnegative mutant was isolated. This mutant (D1) displayed $\mathrm{Mn}$-CD negativity at a wide range of $\mathrm{Mn}$ (II) concentration (1-500 $\mu \mathrm{M})$. It had wild-type colony size, doubling time, and tetracoccal form, but exhibited a significantly lower maximum growth (in c.f.u. $\mathrm{ml}^{-1}$ ), only $1 / 3-1 / 2$ that of IR. Growth curves of IR and D1 in PCB at $32{ }^{\circ} \mathrm{C}$, with or without $\mathrm{Mn}(\mathrm{II})$ addition, are illustrated in Fig. 4. Mn-CD was not observed in D1 (Fig. 4b), indicating a block in the Mn-CD pathway in this mutant. The D1 mutant phenotype was the same at $25^{\circ} \mathrm{C}, 32^{\circ} \mathrm{C}$, and $39^{\circ} \mathrm{C}$, and its general growth characteristics were similar to those of IR. Therefore, D1 is not a temperature-sensitive mutant; it may be defective in certain gene(s) involved in the $\mathrm{Mn}$ $\mathrm{CD}$ pathway, while the gene(s) is not essential for the $\mathrm{N}$ $\mathrm{CD}$ pathway. The successful isolation of such an Mn-CDnegative mutant which differs from the wild-type (IR) specifically in post-exponential physiology supports the inference that the Mn-CD pathway is not essential for cell viability and multiplication in $D$. radiodurans.

\section{The Mn-CD-negative mutation(s) blocks DNA replication}

The Mn-CD-negative mutant D1 was compared with the wild-type strain IR in capability of Mn uptake. Earlystationary-phase cells grown in PCB plus $50 \mu \mathrm{M} \mathrm{Mn}$ (II) were harvested and subjected to inductively coupled plasma atomic emission spectrometry analysis for intracellular Mn concentration by a procedure described by Hawke \& Lloyd (1988). The results showed D1 cells contained $4.5 \pm 0.9 \times 10^{-18} \mathrm{~mol} \mathrm{Mn} \mathrm{c.f.u.}{ }^{-1}$, which was comparable to that of IR $\left(4.7 \pm 1 \cdot 1 \times 10^{-18} \mathrm{~mol} \mathrm{Mn}\right.$ c.f.u. $\left.{ }^{-1}\right)$. Therefore, D1 was not defective in Mn uptake. In another experiment, an early-stationary-phase D1 culture was dispensed into two tubes: $10 \mu \mathrm{M} \mathrm{Mn}(\mathrm{II})$ was added to one, then the tubes were incubated as usual. Cell sizes were monitored by a Coulter counter for up to $4 \mathrm{~h}$. The sizes of $\mathrm{Mn}$ (II)-treated D1 cells were found to be comparable to those of $\mathrm{Mn}$ (II)-untreated cells (e.g. at $1.5 \mathrm{~h}$, the sizes were $9.8 \pm 0.7 \mu \mathrm{m}^{3}$ and $9.7 \pm 0.6 \mu \mathrm{m}^{3}$, respectively). This result indicates that D1 is not a 'division' mutant which is defective in septation or the cell separation step.

Thymidine addition (final concentration of $100 \mu \mathrm{g} \mathrm{ml}^{-1}$ ) 


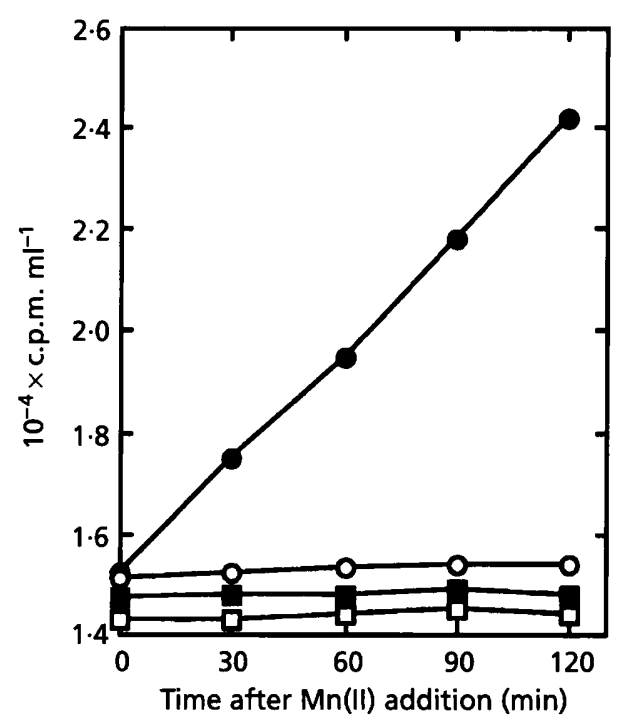

Fig. 5. $\left[{ }^{3} \mathrm{H}\right]$ Thymidine incorporation of the stationary-phase cultures of $D$. radiodurans $I R(O, \theta)$ and $D 1(\square, \square)$ in PCB with $(0, \square)$ and without $(O, \square) \mathrm{Mn}(\mathrm{II})$ addition. Cultures were grown in $\mathrm{PCB}$ to enter stationary phase at $32^{\circ} \mathrm{C}$. Each culture was made in duplicate. $\mathrm{Mn}(\mathrm{II})(10 \mu \mathrm{M})$ and $\left[{ }^{3} \mathrm{H}\right]$ thymidine $\left(20 \mu \mathrm{Ci} \mathrm{ml}^{-1} ; 740 \mathrm{kBq} \mathrm{ml}^{-1}\right)$ were simultaneously added to one of duplicate cultures, and $\left[{ }^{3} \mathrm{H}\right]$ thymidine only was added to the other one. Cultures were sampled at short intervals for determining radioactivities. Individual points represent the mean of three independent measurements differing by less than $10 \%$.

to the stationary-phase cultures of IR and D1 in PCB did not induce extra cell division. The incorporation of $\left[{ }^{3} \mathrm{H}\right]$ thymidine was, therefore, used to measure the DNA synthesis after $\mathrm{Mn}(\mathrm{II})$ addition to the stationary-phase cultures of Mn-CD-positive strain IR and negative strain D1. When $\left[{ }^{3} \mathrm{H}\right]$ thymidine was added $\left[20 \mu \mathrm{Ciml}^{-1}\right.$ $\left(740 \mathrm{kBq} \mathrm{ml}^{-1}\right)$ ] to the stationary-phase cultures of both strains at $32{ }^{\circ} \mathrm{C}$, no significant $\left[{ }^{3} \mathrm{H}\right]$ thymidine incorporation was observed in both cultures (Fig. 5). When $\mathrm{Mn}$ (II) ions $(10 \mu \mathrm{M})$ and $\left[{ }^{3} \mathrm{H}\right]$ thymidine were added simultaneously to those cultures, the incorporation radioactivities of $\left[{ }^{3} \mathrm{H}\right]$ thymidine also could not be detected in D1, but rapid incorporation occurred in IR (Fig. 5). These results indicate that the $\mathrm{Mn}-\mathrm{CD}$-negative mutant $\mathrm{D} 1$ has lost DNA synthesis capability induced by $\mathrm{Mn}$ (II) ions, and suggest that D1 is possibly defective in some step(s) essential for DNA replication in the Mn-CD process, but not in the N-CD process. The mutation(s) in D1 possibly blocks DNA replication, directly or indirectly.

In bacteriophage, DNA replication can be initiated through several different mechanisms (Kornberg, 1980). E. coli has been reported to possess an alternative pathway of DNA replication (Niwa et al., 1979, 1981; Asai \& Kogoma, 1994). In this study, DNA synthesis of $D$. radiodurans TS1 was 'immediately halted' after raising to $39^{\circ} \mathrm{C}$ (Fig. 1b); thus, TS1 is presumably defective in either the production of precursors or the DNAsynthesizing machinery itself but not in initiation of DNA

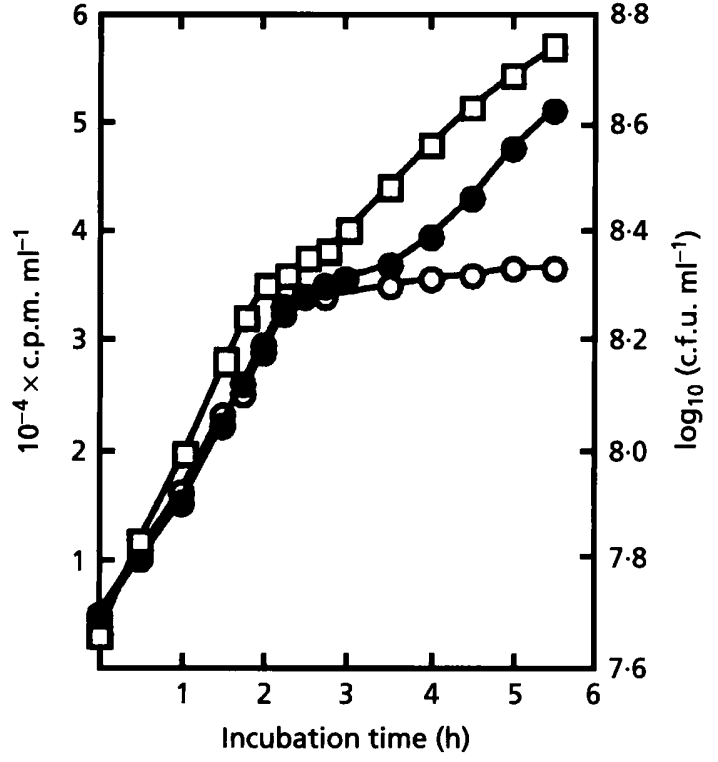

Fig. 6. Transition of growth $(\square)$ and DNA synthesis $(0,0)$ of $D$. radiodurans IR grown in PCB supplemented with $\mathrm{Mn}$ (II). IR cells were grown to late-exponential phase in PCB without $(O)$ and with (O) $\mathrm{Mn}$ (II) addition $(10 \mu \mathrm{M})$, and then $\left[{ }^{3} \mathrm{H}\right]$ thymidine $\left(20 \mu \mathrm{Ci} \mathrm{ml}^{-1} ; 740 \mathrm{kBq} \mathrm{ml}^{-1}\right)$ was added. Radioactivity and c.f.u. measurements were determined by sampling at a short interval. Growth data are means of at least three replications. Individual points of radioactivities represent the mean of three independent measurements differing by less than $10 \%$.

replication (Hirota et al., 1968; von Meyenberg \& Hansen, 1987). TS1 could still exhibit the $\mathrm{Mn}-\mathrm{CD}$ at $39^{\circ} \mathrm{C}$; consequently, we could not rule out the possibility that a different DNA replication pathway may be involved in the $\mathrm{Mn}-\mathrm{CD}$ process.

\section{There is a transition lag in the N-CD to Mn-CD shift}

When $D$. radiodurans IR was grown in PCB containing $10 \mu \mathrm{M} \mathrm{Mn}(\mathrm{II})$, the maximum cell number was about $2 \times 10^{9}$ c.f.u. $\mathrm{ml}^{-1}$, which was almost equal to that obtained from the growth after $\mathrm{Mn}(\mathrm{II})$ addition to its stationary-phase cultures. Obviously, in the former case growth operated through two growth steps, i.e. the normal and the Mn-CD steps. We suppose that a growth transition may occur due to a shift from N-CD to the $\mathrm{Mn}$ $\mathrm{CD}$ pathway when IR cells are cultivated in PCB supplemented with $\mathrm{Mn}$ (II). To test this supposition, a DNA synthesis experiment was conducted. IR cells were grown in $\mathrm{PCB}$, with $(10 \mu \mathrm{M})$ and without $\mathrm{Mn}(\mathrm{II})$ addition, to reach late-exponential phase (approximately $5 \times 10^{7}$ c.f.u. $\left.\mathrm{ml}^{-1}\right)$ and then $\left[{ }^{3} \mathrm{H}\right]$ thymidine $\left[20 \mu \mathrm{Ciml}^{-1}\right.$ $\left.\left(740 \mathrm{kBq} \mathrm{ml}^{-1}\right)\right]$ was added. By sampling at short intervals to determine the incorporation of $\left[{ }^{3} \mathrm{H}\right]$ thymidine, we noted that there was a slower rate of incorporation for a short period that corresponded to the very early stationary phase of normal growth in PCB without $\mathrm{Mn}$ (II) supplementation (Fig. 6). A slight growth lag in that period was also detected in PCB supplemented with Mn(II) (Fig. 
Table 1. Comparison between the cells derived from the $\mathrm{Mn}-\mathrm{CD}$ effect and those from the $\mathrm{N}-\mathrm{CD}$ process

The cultures of $D$. radiodurans IR were grown in PCB medium with shaking at $32{ }^{\circ} \mathrm{C}$.

\begin{tabular}{|c|c|c|}
\hline Property & Mn-CD & N-CD \\
\hline Dividing phase & $\begin{array}{l}\text { Non-exponential; doubling } \\
\text { time increases with time }\end{array}$ & $\begin{array}{l}\text { Exponential phase with } \\
\text { constant doubling time }\end{array}$ \\
\hline Cell size* & Approx. $4 \mu \mathrm{m}^{3}$ & Approx. $9 \mu \mathrm{m}^{3}$ \\
\hline Colony colour & Pale red & Bright red \\
\hline $\begin{array}{l}\text { Sensitivity to salt-mediated } \\
\text { multicell formation effect } \dagger\end{array}$ & No & Yes \\
\hline \multicolumn{3}{|l|}{ Resistance $\left(\mathrm{LD}_{90}\right) \ddagger$} \\
\hline $\mathrm{UV}\left(\mathrm{J} \mathrm{m}^{-\mathbf{2}}\right)$ & 500 & 1350 \\
\hline$\gamma$-Ray (krad) & 420 & 1300 \\
\hline $\mathrm{NTG}\left(\mu \mathrm{g} \mathrm{ml}^{-1} \mathrm{~h}^{-1}\right)$ & 435 & 1225 \\
\hline $\operatorname{MMC}\left(\mu \mathrm{g} \mathrm{ml}^{-1} \min ^{-1}\right)$ & 70 & 215 \\
\hline \multicolumn{3}{|c|}{ Specific activity [U (mg proteins) $\left.)^{-1}\right] \S$} \\
\hline Superoxide dismutase & 94 & 19 \\
\hline Catalase & 1200 & 710 \\
\hline
\end{tabular}

* Mean volumes of N-CD cells (early-stationary phase) and $\mathrm{Mn}$-CD cells [those at $11 \mathrm{~h}$ after $\mathrm{Mn}$ (II) addition to an early-stationary-phase culture] were determined with a Coulter counter.

t Refer to Chou \& Tan (1991) for this multicell formation effect. $\mathrm{NaCl}(0 \cdot 2-1 \cdot 2 \%)$ was added to an exponential-phase culture (N-CD) and a dividing Mn-CD culture [those at $5 \mathrm{~h}$ after $\mathrm{Mn}$ (II) addition to an early-stationary-phase culture].

$\ddagger L D_{90}$ is the dose of radiation which kills $90 \%$ of the exposed cells; data were those for early-stationaryphase cells. Refer to Chou \& Tan (1990) for the results of UV and $\gamma$-ray treatments. Cells were treated with $350 \mu \mathrm{g} \mathrm{NTG} \mathrm{ml}^{-1}$ and $5 \mu \mathrm{g}$ mitomycin C (MMC) $\mathrm{ml}^{-1}$.

$₫$ Refer to Chou \& Tan (1990).

6). This suggests that the incorporation (or growth) lag appears to be the result of a growth transition from N-CD to the Mn-CD stage. This transition lag is reminiscent of a similar lag seen late in liquid culture of Streptomyces spp. (Holt et al., 1992; Leskiw et al., 1993) that seems to involve major changes in protein profiles.

\section{Characteristics of the Mn-CD process}

The results obtained from this and previous studies show that cells undergoing Mn-CD display profound physiological changes, as compared with cells derived from the N-CD process (Table 1). In B. subtilis (Oh \& Freese, 1976) and Lactobacillus plantarum (Archibald \& Fridovich, 1981), $\mathrm{Mn}$ (II) supplementation is required for optimal growth. In these cases, $\mathrm{Mn}$ (II) deficiency results in a halt in growth at a low cell number, and the exponential growth rate is increased with $\mathrm{Mn}(\mathrm{II})$ addition within a dose range. In contrast, in $D$. radiodurans $\mathrm{Mn}$ (II) addition to the medium increases the maximum cell numbers, but not the exponential growth rate (Chou \& Tan, 1990). Obviously, different mechanisms of maximum growth enhancement appear to be used in these two cases; the Mn-CD process should not be considered as simply an outcome of optimization of growth conditions. The significant difference of physiological response in $\mathrm{Mn}-\mathrm{CD}$ cells in comparison with N-CD cells indicates that the onset of the stationary phase, i.e. the shutdown of the N-CD pathway, is not due to $\mathrm{Mn}(\mathrm{II})$ deficiency in the growth medium. $\mathrm{Mn}$ (II) may be involved in an induction process which initiates an alternative growth pathway; otherwise the physiological properties of $\mathrm{Mn}-\mathrm{CD}$ cells in $\mathrm{Mn}$ (II)supplemented medium would be similar to those of N-CD cells in control medium.

The Mn-CD effect produces highly modified cells and appears to be Deinococcus-specific. It can provide an attractive system for studying the many novel physiological and genetic properties in deinobacteria which are largely not elucidated (Work, 1964; Baumeister et al., 1986; Counsell \& Murray, 1986; Chou \& Tan, 1991; Murray, 1992). For example, the fact (Table 1) that in the progression of the $\mathrm{Mn}-\mathrm{CD}$ cycles cells concomitantly lose their resistance to a variety of DNA-damaging agents and increase synthesis of the free radical scavenging enzyme superoxide dismutase should render the Mn-CD effect useful for studying the mechanism of radioresistance in D. radiodurans. Recently, Minton (1994), based on extensive genetic studies, suggested that the extremely high radioresistance in deinobacteria be attributed to an effective way of interchromosomal recombination. Being a reductive type of growth, the $\mathrm{Mn}-\mathrm{CD}$ process possibly produces cells successively lessening in genome multiplicity or failing in synthesis of a factor(s) critical to the extreme radioresistance. 


\section{ACKNOWLEDGEMENTS}

The authors would like to thank Drs W. G. Chou, Carton W. Chen, H. Y. Sun and W. Y. Hsieh for critical reading of the manuscript. This research was supported by grants from the National Science Council (NSC-80-0203-B-007-11) and the Atomic Energy Council (82-2001-DRP-034) of the Republic of China.

\section{REFERENCES}

Anderson, A. W., Nordan, H. C., Cain, R. F., Parrish, G. \& Duggan, D. (1956). Studies on a radio-resistant micrococcus. I. Isolation, morphology, cultural characteristics, and resistance to gamma radiation. Food Technol 10, 575-578.

Archibald, F. S. \& Fridovich, I. (1981). Manganese and defenses against oxygen toxicity in Lactobacillus plantarum. J Bacteriol 145, 442-451.

Asai, T. \& Kogoma, T. (1994). D-loops and R-loops: alternative mechanisms for the initiation of chromosome replication in Escherichia coli. J Bacteriol 176, 1807-1812.

Bascarán, V., Sánchez, L., Hardisson, C. \& Braña, A. F. (1991). Stringent response and initiation of secondary metabolism in Streptomyces clavuligerus. J Gen Microbiol 137, 1625-1634.

Baumeister, W., Barth, M., Hegerl, R., Guckenberger, R., Hahn, M. \& Saxton, W. O. (1986). Three-dimensional structure of the regular surface layer (HPI layer) of Deinococcus radiodurans. J Mol Biol 187, 241-253.

Boylan, R. J. \& Mendelson, N. H. (1969). Initial characterization of a temperature-sensitive rod $^{-}$mutant of Bacillus subtilis. $J$ Bacteriol 100, 1316-1321.

Chou, F. I. \& Tan, S. T. (1990). Manganese(II) induces cell division and increases in superoxide dismutase and catalase activities in an aging deinococcal culture. J Bacteriol 172, 2029-2035.

Chou, F. I. \& Tan, S. T. (1991). Salt-mediated multicell formation in Deinococcus radiodurans. J Bacteriol 173, 3184-3190.

Counsell, T. J. \& Murray, R. G. E. (1986). Polar lipid profiles of the genus Deinococcus. Int J Syst Bacteriol 36, 202-206.

Evans, D. M. \& Moseley, B. E. B. (1985). Identification and initial characterisation of a pyrimidine dimer UV endonuclease (UV endonuclease $\beta$ ) from Deinococcus radiodurans; a DNA-repair enzyme that requires manganese ions. Mutat Res 145, 119-128.

Gramajo, H. C., Takano, E. \& Bibb, M. J. (1993). Stationary phase production of the antibiotic actinorhodin in Streptomyces coelicolor A3(2) is transcriptionally regulated. Mol Microbiol 7, 837-845.

Groat, R. G., Schultz, J. E., Zychlinsky, E., Bockman, A. \& Matin, A. (1986). Starvation proteins in Escherichia coli: kinetics of synthesis and role in starvation survival. J Bacteriol 168, 486-493.

Hawke, D. J. \& Lloyd, A. (1988). Determination of metals in sewage sludge by inductively coupled plasma atomic emission spectrometry using a simplified nitric acid digestion method. Analyst 113, 413-417.

Hirota, Y., Ryter, A. \& Jacob, F. (1968). Thermosensitive mutants of E. coli affected in the processes of DNA synthesis and cellular division. Cold Spring Harbor Symp Quant Biol 33, 677-693.

Holt, T. G., Chang, C., Laurent-Winter, C., Murakami, T., Garrels, J. I., Davies, J. E. \& Thompson, C. J. (1992). Global changes in gene expression related to antibiotic synthesis in Streptomyces hygroscopicus. Mol Microbiol 6, 969-980.

Jenkins, D. E., Chaisson, S. A. \& Matin, A. (1990). Starvationinduced cross protection against osmotic challenge in Escherichia coli. J Bacteriol 172, 2779-2781.
Kornberg, A. (1980). DNA Replication, pp. 347-414. San Francisco: W. H. Freeman.

Kubitschek, H. E. (1990). Cell volume increase in Escherichia coli after shifts to richer media. $J$ Bacteriol 172, 94-101.

Leibowitz, P. J., Schwartzberg, L. S. \& Bruce, A. K. (1976). The in vivo association of manganese with the chromosome of Micrococcus radiodurans. Photochem Pbotobiol 23, 45-50.

Leskiw, B. K., Mah, R., Lawlor, E. J. \& Chater, K. F. (1993). Accumulation of bld $A$-specified tRNA is temporally regulated in Streptomyces coelicolor A3(2). J Bacteriol 175, 1995-2005.

Lillie, S. H. \& Pringle, J. R. (1980). Reserve carbohydrate metabolism in Saccharomyces cerevisiae: responses to nutrient limitation. J Bacteriol 143, 1384-1349.

von Meyenberg, K. \& Hansen, F. G. (1987). Regulation of chromosome replication. In Escherichia coli and Salmonella typhimurium: Cellular and Molecular Biology, vol. 2, pp. 1555-1577. Edited by F. C. Neidhardt, J. L. Ingraham, K. Brooks Low, B. Magasanik, M. Schaechter \& H. E. Umbarger. Washington, DC: American Society for Microbiology.

Minton, K. W. (1994). DNA repait in the extremely radioresistant bacterium Deinococcus radiodurans. Mol Microbiol 13, 9-15.

Moseley, B. E. B. (1983). Photobiology and radiobiology of Micrococcus (Deinococcus) radiodurans. Photochem Pbotobiol Rev 7, 223-275.

Murray, R. G. E. (1992). The family Deinococcaceae. In The Prokaryotes: a Handbook on the Biology of Bacteria. Ecophysiology, Isolation, Identification, Applications, 2nd edn, vol. IV, pp. 3732-3744. Edited by A. Balows, H. G. Trüper, M. Dworkin, W. Harder \& K.-H. Schleifer. New York: Springer-Verlag.

Nicholson, W. L. \& Setlow, P. (1990). Sporulation, germination and outgrowth. In Molecular Biological Methods for Bacillus, pp. 391-450. Edited by C. R. Harwood \& S. M. Cutting. Chichester: John Wiley.

Niwa, O., Bryan, S. K. \& Moses, R. E. (1979). Replication at restrictive temperatures in Escherichia coli containing a polCts mutation. Proc Natl Acad Sci US A 76, 5572-5576.

Niwa, O., Bryan, S. K. \& Moses, R. E. (1981). Alternate pathways of DNA replication: DNA polymerase I-dependent replication. Proc Natl Acad Sci US A 78, 7024-7027.

Nyström, T., Flärdh, K. \& Kjelleberg, S. (1990). Responses to multiple-nutrient starvation in marine Vibrio sp. strain CCUG 15956. J Bacteriol 172, 7085-7097.

Oh, Y. K. \& Freese, E. (1976). Manganese requirement of phosphoglycerate phosphomutase and its consequence for growth and sporulation of Bacillus subtilis. J Bacteriol 127, 739-746.

Oke, V. \& Losick, R. (1993). Multilevel regulation of the sporulation transcription factor $\sigma^{\mathrm{K}}$ in Bacillus subtilis. J Bacteriol 175, 7341-7347.

Siegele, D. A. \& Kolter, R. (1992). Life after log. J Bacteriol 174, 345-348.

Spector, M. P., Aliabadi, Z., Gonzales, T. \& Foster, J. W. (1986). Global control in Salmonella typhimurium: two dimensional electrophoretic analysis of starvation-, anaerobiosis-, and heat shockinducible proteins. J Bacteriol 168, 420-424.

Tan, S. T. (1982). Radiation resistance of a bemolytic micrococcus isolated from chicken meat. PhD thesis, University of Nebraska, USA.

Tan, S. T. \& Maxcy, R. B. (1982). Inactivation and injury of a hemolytic radiation-resistant micrococcus isolated from chicken meat. J Food Sci 47, 1345-1349, 1353.

Tan, S. T. \& Maxcy, R. B. (1986). Simple method to demonstrate 
radiation-inducible radiation resistance in microbial cells. $A p p l$ Environ Microbiol 51, 88-90.

Wierowski, J. V. \& Bruce, A. K. (1980). Modification of radiation resistance by manganese in Micrococcus radiodurans. Radiat Res $\mathbf{8 3}$, 384.

Woese, C. R. (1987). Bacterial evolution. Microbiol Rev 51, 221-271.
Work, E. (1964). Amino-acids of walls of Micrococcus radiodurans. Nature 201, 1107-1109.

Received 14 December 1994; revised 27 February 1995; accepted 21 March 1995. 